\title{
Assessment of Socio-Educational Status of Irula Tribe School Students in Coimbatore, Tamil Nadu
}

\author{
R Balamurali Krishna ${ }^{1}$, Dr. N Prathiba ${ }^{2}$
}

\section{ABSTRACT}

The aim of the study is to assess the socio-educational status of Irula tribe middle adolescent school students in the hilly hamlets of Kunjapanai and Anakati, the most backward regions of Coimbatore district of Tamil Nadu. The study focuses on 6 areas namely, School Curriculum, Parental Role, Sports, Sanitation, Awareness and Abuse. The Findings and recommendations of the study have been documented. The key highlights of the study admits that majority ( 74\%) of the students rate their school as 'Average' due to the poor infrastructure; Didactic mode of teaching is still dominant; Parents role is minimal in their children's academics; No formal exposure to Sports is available for students, even though $\sim 64 \%$ of them prefers to participate in sports and games; Lack of toilet facility, cleanliness and maintenance compels the students to opt for practicing the open defecation; Majority of students don't have appropriate awareness regarding their career growth. Lastly, almost ( 96\%) of the students has been subjected to Corporal Punishment in one-way or the other. These need of the students' voices for proactive intervention of Panchayat, NGOs and local bodies to ameliorate the condition.

Keywords: Adolescence, Curriculum, Sports, Sanitation, Career Awareness, Physical Abuse

India being a diverse and secular country, houses a vast number of tribal community. There are around 705 major STs enlisted in the Constitution of India. Total population of scheduled tribes in India is 10,42 , and 81,034 as per the Census 2011, which accounts for $8.6 \%$ of the total population of the country. The Adolescent population (10-19 years of age) among STs is around 2 , 32, and 73,430 which accounts for $22.32 \%$ of the total ST population. Literacy rate among tribal population is $59 \%$ which is less than the national average of $73 \%$. Education is considered to be stepping stone for socio-economic development as it creates awareness and provides opportunities. Article 21A of the Indian constitution states 'The State shall provide free and compulsory education to all children of the age of six to fourteen years in such manner as the State may by law determine'. Thus, it makes education as a fundamental right. Article 51A (k)

\footnotetext{
${ }^{1}$ Ph.D Scholar, Department of Social Work, Karpagam University, Tamil Nadu, India

${ }^{2}$ Assoc. Professor, Department of Social Work, Karpagam University, Tamil Nadu, India

*Responding Author

(C) 2016 Balamurali K, Prathiba N; licensee IJIP. This is an Open Access Research distributed under the terms of the Creative Commons Attribution License (http://creativecommons.org/licenses/by/2.0), which permits unrestricted use, distribution, and reproduction in any Medium, provided the original work is properly cited.
} 
states 'It shall be the duty of every citizen who is a parent or guardian to provide opportunities for education to his child or, as the case may be, ward between the age of six and fourteen years', which makes providing education to their children as a fundamental duty for parents. Although, these measures were able to achieve an increase in general literacy rate, yet educational status of the disadvantaged groups, particularly, the STs is in pathetic condition, even after 70 years of Indian independence. There are several clogging factors such as socioeconomic condition, societal attitude, interest of the parents to educate their children, the awareness regarding education avenues and many others. For a tribal family to send a boy or a girl to school is essentially a matter of economy and entails dislocation in the traditional pattern of their labor force. Many tribal groups refrain from sending children to school due to loss of good characteristic of the labor force and the fear of expenditure on education (like tuition, additional text books etc.). There is an utmost need to change this trend. This study assesses the socio-educational status of middle adolescent Irula tribe school students in Coimbatore district and it advocates for an educational system that should be of pragmatic nature with the inclusion of life skills that will lead to comprehensive development in society.

\section{IRULA TRIBE - A BRIEF OUTLOOK}

Irulas a sect of primitive tribe found in the southern belt of India in the states of Tamil Nadu, Kerala and Karnataka. In Tamil Nadu, they are referred as 'Irular' and noted as the Particularly Vulnerable Tribal Group (PVTG). They are one among the 6 notified primitive tribal groups in the state. In comparison with other tribal groups, Irulas are backward in Education and Employment. Only Education can transform a community at large. But their literacy rate among the adult population is less than $5 \%$. Since they are in semi nomadic nature, they do not realize the significant of the education. Recent studies ascertain that their school enrolment was less than $40 \%$ especially in the age group of 6 to 14 . The drop out is high among girls especially after attaining puberty. There are several factors that influence the education of children in Irula society. Earlier Government had no direct programme for their education. But in the subsequent years the reservation policy has made some changes. Though there are many reasons for low level of education among this tribal people; one such reason is that formal education is not considered necessary to discharge their social obligations. In this study, authors assessed the socio-educational status among $9^{\text {th }}$ and $11^{\text {th }}$ standard school students (middle adolescents) of Irula tribes in two hamlets of Coimbatore, Tamil Nadu.

\section{Objective of the Study}

The study aims to assess the socio-educational status of Irula tribe school students (middle adolescents) in Coimbatore district of Tamil Nadu and it highlights their vulnerabilities and obstacles in accessing opportunities and services. In this study, the Middle Adolescents has been defined as youngsters between 15-19 years of age in conformance with Ministry of Health and Family Welfare, WHO, and UNICEF norms. The broad objectives of this study are, 
1. To appraise the effectiveness of our socio-educational system in inculcating the social, ethical, moral values and academic awareness \& skills among Irula tribe school students by self-devised E-questionnaire.

2. To collate information on the contemporary needs of middle adolescents and to identify the need gaps and challenges.

3. To provide suggestions for future areas of research and evidence gathering.

\section{RESEARCH_METHODOLOGY}

\section{Research Design}

This is a Descriptive Study and it aims to describe the socio-educational state of Irula school students as it exists at present.

\section{Universe}

The universe of the study is Irula tribe govt. school students (middle adolescents), i.e., 15-19 year age group students from the hilly hamlets of Kunjapanai and Anakatti in Coimbatore District, Tamil Nadu.

\section{Data Collection}

Study adopted Simple Random Sampling technique to collect the Primary data among the Irula tribe school students. The authors devised a Semi-Closed E-questionnaire, supported by '5G Research' an e-tool for primary data collection. The E-questionnaire was framed according to the study objectives with embedded pictorial images.

The primary data was collected from 53 students in which 27 respondents were from Kunjapanai and 26 respondents were from Anakatti hamlets. The data was collected through electronic mode (using Laptop and Smartphone). Gender specific information about the sample is given in the below table.

\begin{tabular}{llll}
\hline Class & Boys & Girls & Total \\
\hline $\mathbf{9}^{\text {th }}$ & 14 & 13 & 27 \\
$\mathbf{1 1}^{\text {th }}$ & 13 & 13 & 26 \\
Total & 27 & 26 & 53 \\
\hline
\end{tabular}

Focus Areas

The study focuses on the following areas:
A. Notion on School \& Teachers
B. Parent-Teacher Interaction
C. Sports \& Extra-curriculum Exposure
D. Hygiene \& Sanitation
E. Career Awareness
F. Corporal Punishment 


\section{FINDINGS \& DISCUSSIONS}

\section{Notion on School \& Teachers}

Education is most important element for the development of tribal community. It is a powerful instrument to change the values and attitude of the people and to create in them the urge of the necessary motivation to achieve social mobility and ascendancy. Various efforts have been made by the Government as well as NGOs to educate the masses, but still the literacy rate of the tribal community is very low. There are several hindering factors such as socio-economic condition, interest of the parents to educate their children etc. In Tamil Nadu, provision of tribal education is important since tribal population (PVT) accounts for $1.1 \%$ of the state total population (Census 2011). This study ascertains the middle adolescents' relationship with their School Teachers and perception towards their School Setting.

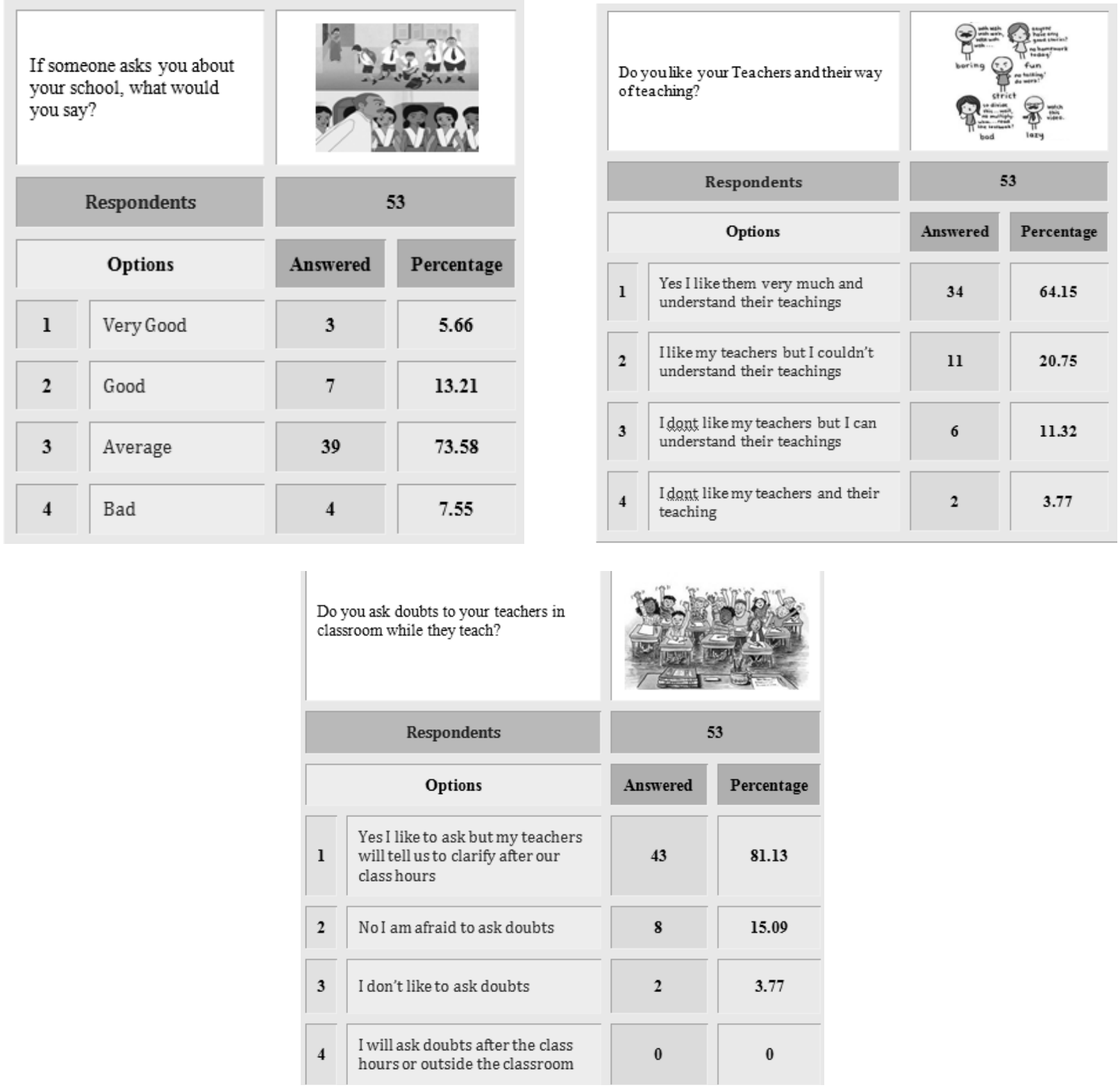


The study establishes the fact that majority ( 74\%) of the students rate their school as 'Average'. It is visibly evident from the prevailing school infrastructure. To improve the present conditions, the Village Panchayat intervention is substantial. With respect to the relationship with their School Teachers, even though the findings reflect in positive outlook yet there prevails a lacuna with respect to 'Doubt Clarification'. It is evident from the study, although students prefer interactive teaching methodology, yet still the didactic mode of teaching is dominant. This opens a Pandora box to revive the teaching strategy among teachers. The role of Mass Media, Smartphone and Mobile Apps needs to be harnessed in educational development of tribes, particularly students.

\section{Parent - Teacher Interaction}

In-spite of the various constitutional safeguards and different schemes by government the literacy level of the tribal is found to be much lower than that of the rest of the society. Interest and support of the parents to educate their children is very crucial. In general, the parents of the high achievers exert significantly more support to their children's studies than the parents of low achieving students. This study aims to explore the parents' awareness on children's academic and routine affairs; and also on parent-teacher interaction and relationships.
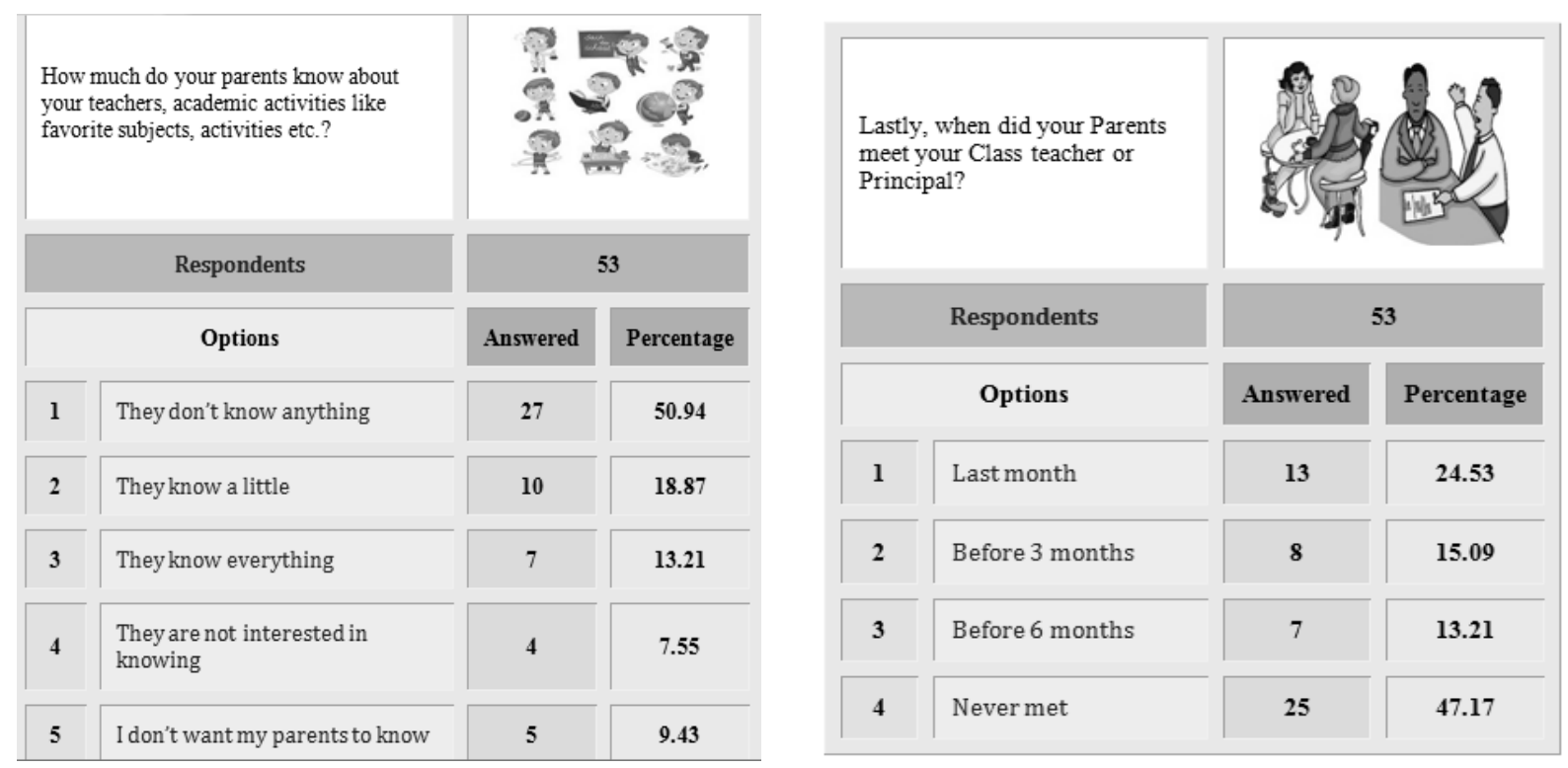

The study reveals that nearly about ( 66\%) of parents lack effective knowingness about their children's academic and routine affairs.

In addition, it is evident from the study that there is no formal and periodical "Parent-Teacher Meeting” in the tribal schools as compared to the other Govt/Private schools in the state. Jayaswal, et.al, (2003) opined that the parents of high achievers will have greater work commitment concern with the quality of performance and inclination to learn lessons from others, 
more interest in children's academic success. On the other hand the parents of low achievers may not have strong ambitiousness on their children' upward mobility and are fatalistic, lacking a role model and having low self-confidence and initiative to guide their children. Thus, this concern and need gap of tribal students must be addressed and tribal parents today, should be encouraged to exhibit a positive attitude towards their children's education.

\section{Sports \& Extra-Curriculum}

School Sports as a part of school physical education has a vital role in the education of young people, particularly middle adolescents. It improves students' concentration, memory, behaviour and academic performance. On the backdrop of Rio Olympics 2016, Hon. Indian Prime Minister announced that Govt of India would set up a task force to create a strategy to help sportspersons prepare for the next 3 Olympics; that advocates compulsory Sports \& Gamming activities in all schools. Today, research shows that the need for physical activity in children is stronger than ever. In this study, authors highlight the prevailing plight of Sports, Games and Extra-curricular exposure opportunities like NCC, NSS, and NGC etc. available for tribal school students.
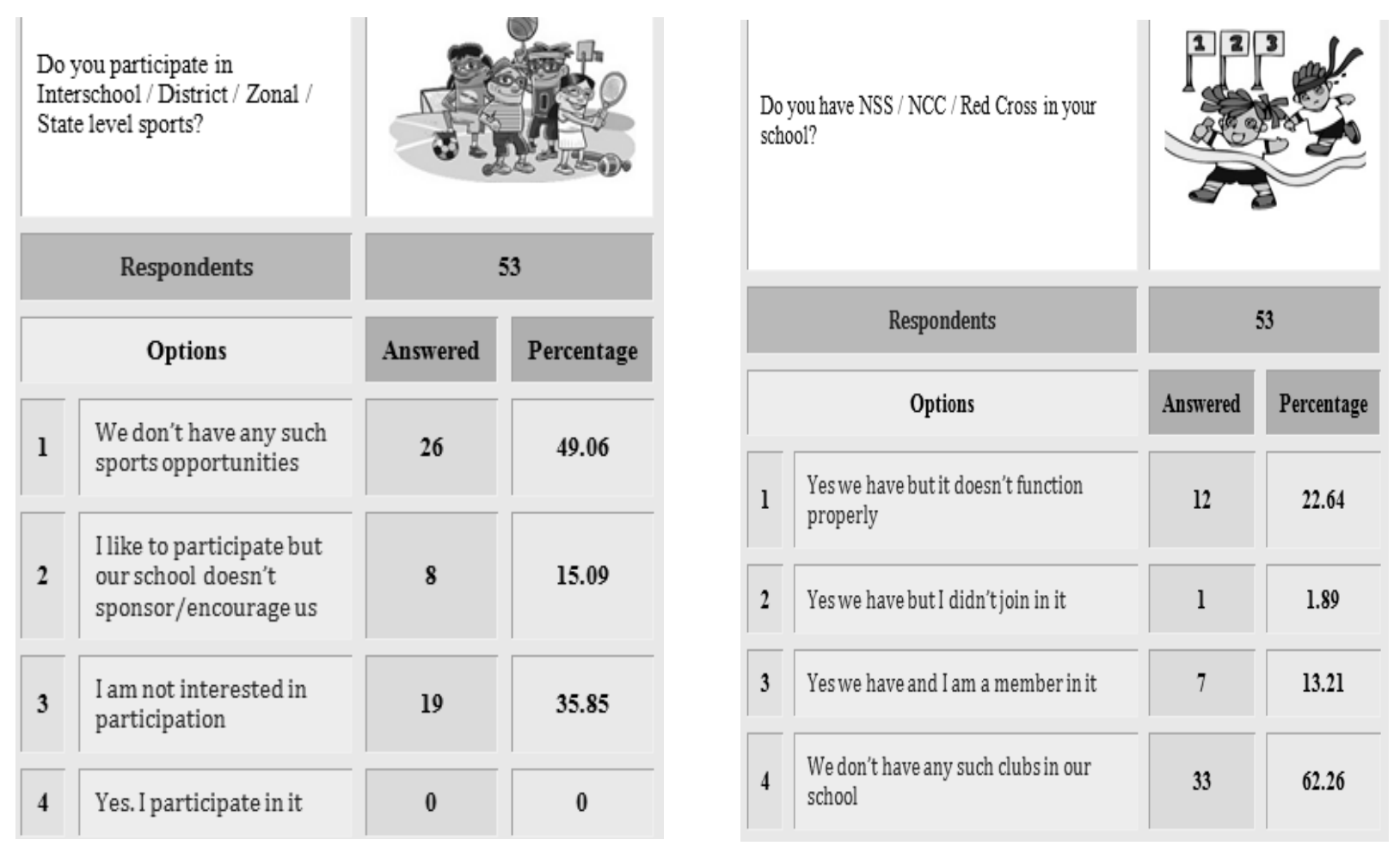

The study discovers that no such formal exposure to Sports like Sports day, Intra or Inter-School Competitions is made available for tribal students; even though ( 64\%) of them prefers to participate in Sports and only ( 36\%) of the students doesn't like to participate in such activities. This pushes the tribal students to a boredom state. Even the Govt. sponsored service/club activities like NCC; NSS etc. are not effectively available to them. This reveals the ground reality of social exclusion being faced by the tribal students at their tender age itself; in-spite of 
their innate interest towards extra-curricular activities \& Sports. Considering the present scenario, the Panchayat should intervene to develop sports and allied activities in tribal schools by pooling the financial resources via Grants, CSR funding and other sources.

\section{Hygiene \& Sanitation}

Open defecation practice still remains intransigently widespread in rural India, despite economic growth, Govt's wet latrine constructions, and increasing recognition among policy-makers that it constitutes a health and human capital crisis. According to Census 2011, 67\% of the rural Indian households are defecating in the open areas. This study examines the causes of open defecation practice by school students and availability of toilets in the school premises.
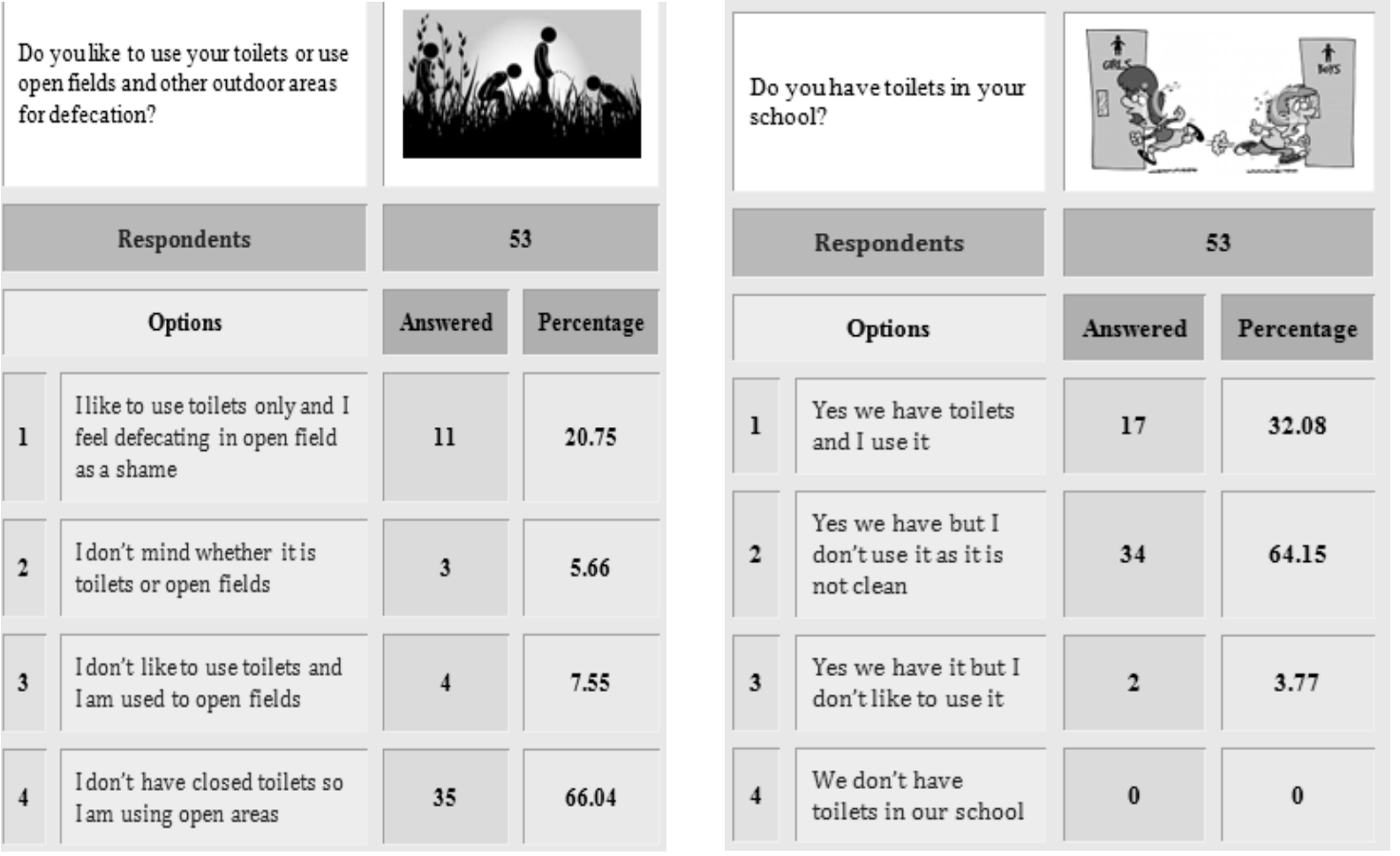

From the study results, it is apparent that due to the lack of hygienic toilet facility, open defecation is being practised by majority of the students. Moreover, lack of cleanliness and maintenance of toilets compels the students to opt for open defecation. The local bodies should treat this problem seriously and steps to be taken for construction of proper toilets.

Menstruation is generally considered as unclean affair in Indian society. Isolation of the menstruating girls and restrictions being imposed on them in the family, have reinforced a negative attitude towards this phenomenon. There is a substantial lacuna in the knowledge about menstruation among adolescent girls. Good hygienic practices such as the use of sanitary pads and adequate washing of the genital area are essential during menstruation. This study examines the practise of sanitary napkin usage among adolescent school girls during menstruation. 
Assessment of Socio-Educational Status of Irula Tribe School Students in Coimbatore, Tamil Nadu

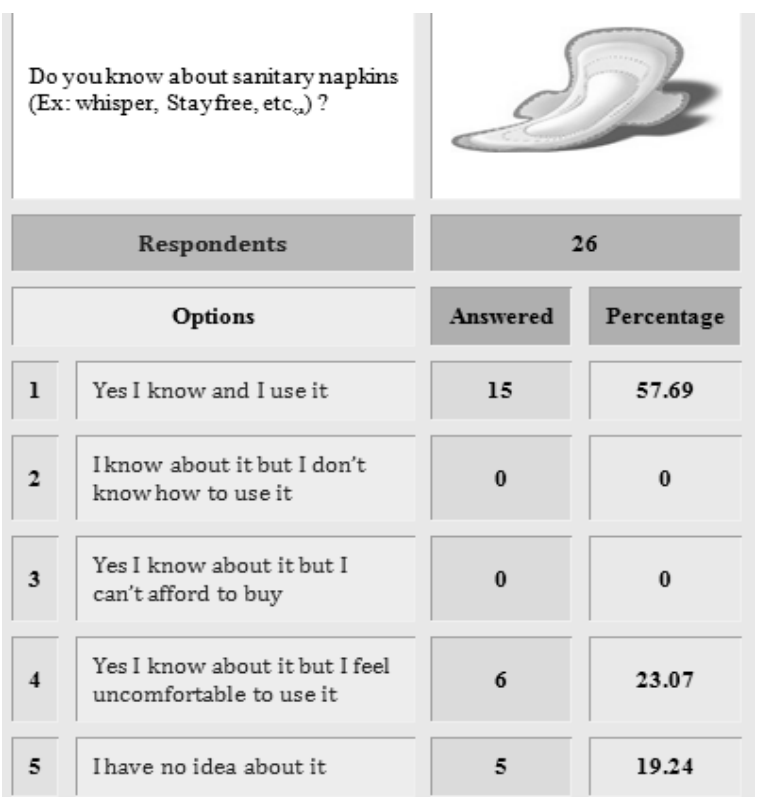

Findings from the study shows that the majority of adolescent girls have the healthy practise of using sanitary napkins but still there is need for dissemination of advantages on using sanitary napkins during menstrual days; with role of teachers advocating for it.

\section{Career Awareness}

The reservation policy has opened the gates to the backward sections of society like SCs and STs for the premier education institutions like IITs, AIIMS etc.. But the awareness for achieving those standards is still missing among the tribal students. This study looks into the awareness level among tribal students regarding their career growth.

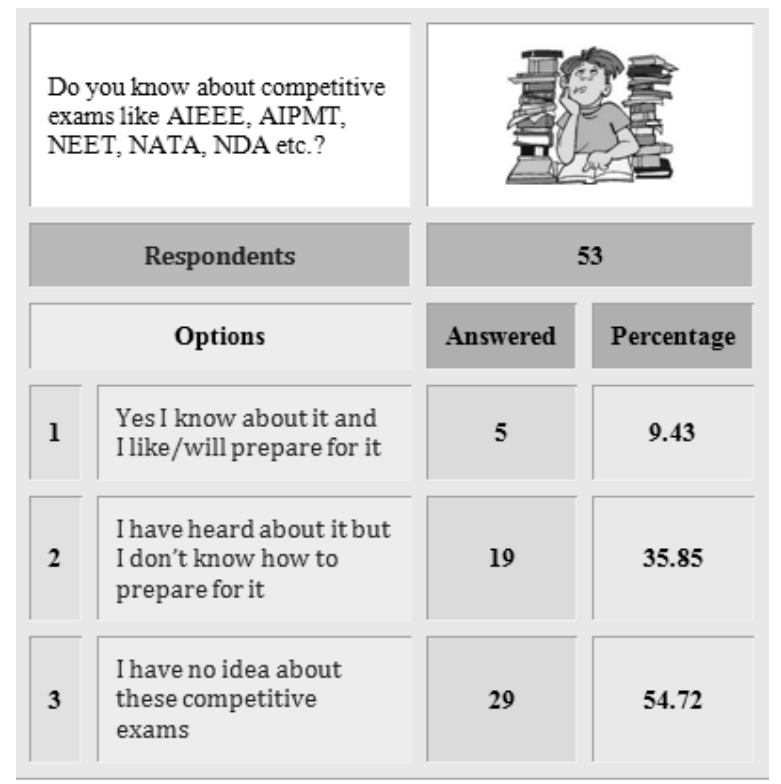

It is clearly visible from the above findings that majority of students don't have proper awareness regarding their career and ways to achieve that; it is a sorrow state that even the teachers have 
not shown much interest to propagate it. This attitude of teachers should be changed and the students should be well informed in the present competitive world.

\section{Corporal Punishment in School}

Physical abuse in schools, also referred as 'Corporal punishment', is the deliberate infliction of pain intended to change a person's behaviour or to punish him/her. It does not produce longlasting changes in behaviour; negatively affects the social, psychological, and educational development of students; contributes to the cycle of child abuse; and promotes pro-violence attitudes of youth (Ander \& Stewart, 2002). Although Corporal punishment is prohibited in schools by the RTE Act 2009, but it is still prevalent among rural regions. This study probes the occurrence of any such acts being practiced by the tribal school teachers.
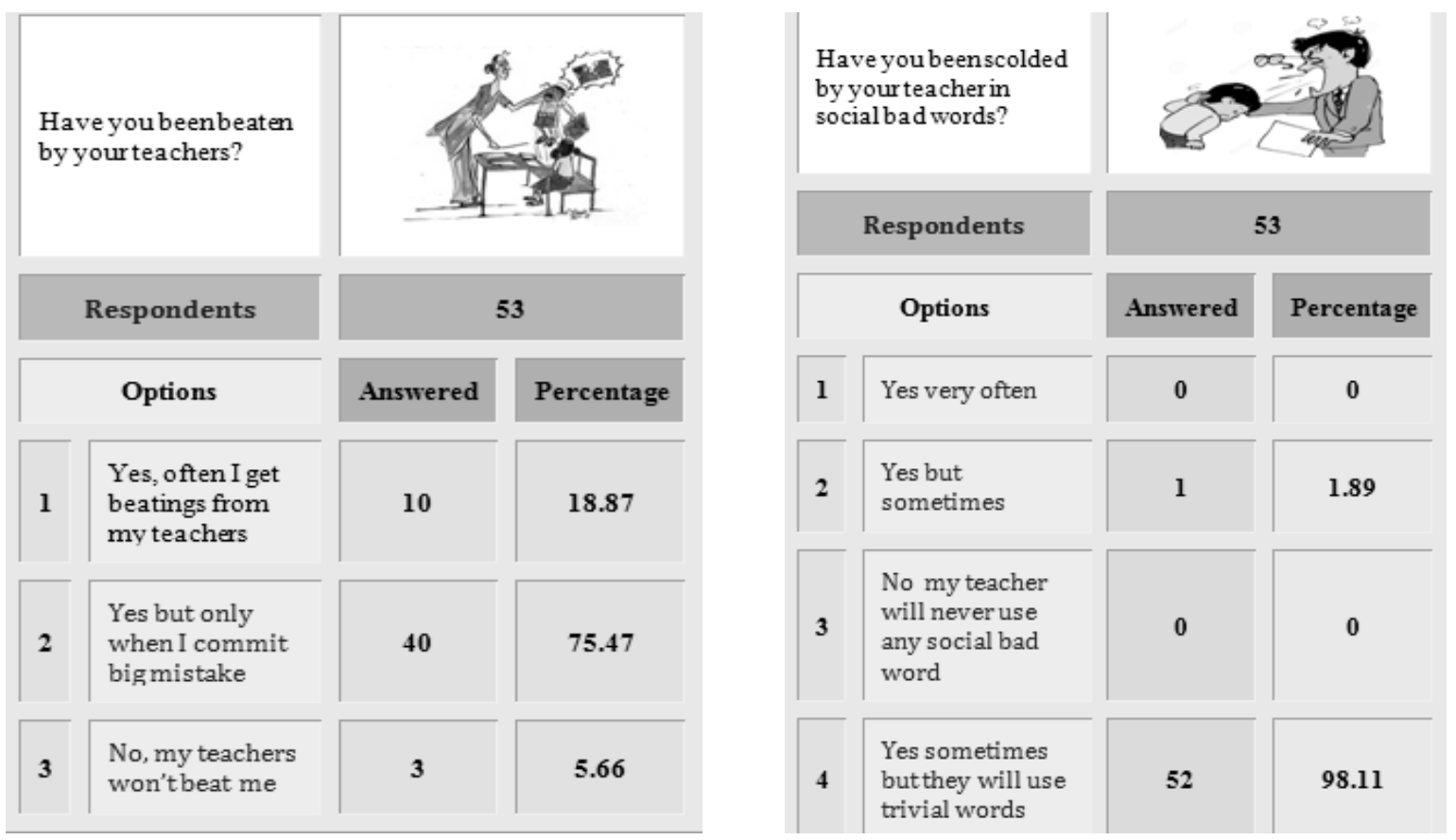

The study exposes a shocking discovery that almost ( 96\%) of the tribal adolescents has been subjected to corporal punishment. Also the adolescent girls are vulnerable to pinches and boys are susceptible to beatings by hand, stick, wooden scale etc. by their teachers. The study also probes into the practise of using verbal abusive words by the teachers.

The study discovers that students have inculcated the usage of trivial abusive word by their teachers as a plebeian and accepts it. The RTE act, intrinsically expresses that the use of violent behaviour against students is never an acceptable means of punishment - it harms students physically, psychologically and academically. The increased parental involvement, improved teacher training and the development of specific discipline plans would all help to improve student conduct. The teachers should be educated in the use of alternative methods of discipline, 
with a special emphasis on employing evidence based behaviour modification and other strategies, techniques to maintain control of the classroom without resorting to violence.

\section{CONCLUSION}

Middle adolescence being the transition stage from childhood to adulthood sets the stage for adult life that depends largely on how well they navigate this transition. The education status of Irula middle adolescents in remote regions like Kunjapanai, Anakkati are low as compared to other communities. Being in the most social and economically backward regions of the State, their voices are often unheard. This study suggests that although government actions, endeavours of universalizing education has resulted in generating mass awareness and positive response towards schooling and education yet still, there is huge need for improvement in the tribal schools. Proactive Intervention is required in the areas like Teaching Quality, School \& Classroom Infrastructure, Parent Responsibility, Exposure to Sports \& Games, Sanitation and eradication of abuses inside school premises. These needs and challenges of Irula tribe school students' advocates for proactive involvement of local bodies to effectively utilize the development funds. Therefore, the study emphasizes to harness Smartphone as a tool for behavioural change to foster adolescents' mental health.

\section{Acknowledgments}

Our Grateful thanks to the Tribal Development Experts viz. Mr. GM Dhiwakar and Ms. K Kunguma Gayathri, Transmission Executives in Doordarshan Kendra, Government of India for their valuable suggestions and comments.

\section{Conflict of Interests}

The author declared no conflict of interests.

\section{REFERENCES}

Baskar R \& Karthikeyan A (2015). A Study on Educational Awareness among Irula Parent's in Tholampalyam \& Velliangadu Panchayat in Coimbatore district, Tamil nadu, Department of Social Work, Bharathiar University. - Indian Journal Of Applied Research, Volume: 5, Issue: 12, Special Edition - Dec. 2015

Census 2011

Detailed notes of Irulars - https://www.wikipedia.com/

Gnanamoorthy K (2015). Present Situation of Irular - A Primitive Tribe, Department of Economics, Presidency College, (Autonomous), Chennai. - IOSR Journal of Economics and Finance (IOSR-JEF) e-ISSN: 2321-5933, p-ISSN: 2321-5925.Volume 6, Issue 1. Ver. II (Jan.-Feb. 2015), PP 46-49

Jakkar Parthasarathy (2007), "Education and Development among the Tribes - A Study of Formal Education and Tribal Girl Child Dropouts in the Nilgris District, Tamil Nadu”, Tribal Research Centre (TRC), Udagamandalam, Nilgiris, Tamil Nadu. 
Jayaswal, M., Sinha, S.K., Kumari, K. and Arora, A. (2003), Parental Support and Academic Achievement in Tribal School Students of Jharkhand, Journal of All India Association for Educational Research, September, Vol. 15, No.3, Pp: 9-16.

Krithiga K and Annapoorani R (2011). Educational Status of STs in Nilgiris District, Avinashiligam University for Women, Coimbatore. - Ph.D Thesis in Economics.

Rajam V \& Malarvizhi V (2011). A Study on Educational Status of Tribal Children in the Nilgris District, Avina shilingam Institute for Home Science and Higher Education for Women, Coimbatore. - ZENITH International Journal of Business Economics \& Management Research Vol.1 Issue 2, Nov 2011, ISSN 22498826

Tamil Nadu State $12^{\text {th }}$ Five Year Plan.

How to cite this article: Balamurali K, Prathiba N (2016), Assessment of Socio-Educational Status of Irula Tribe School Students in Coimbatore, Tamil Nadu, International Journal of Indian Psychology, Volume 4, Issue 1, No. 82, ISSN:2348-5396 (e), ISSN:2349-3429 (p), DIP:18.01.144/20160401, ISBN:978-1-365-59365-9 